\title{
Medication Storage Appropriateness in US Households
}

Olivia G. Funk, BPS'; Royce Yung, MBA'; Scott Arrighi, BS Biology ${ }^{3}$ SuHak Lee, PharmD ${ }^{4}$

${ }^{1}$ Long Island University Arnold \& Marie Schwartz College of Pharmacy and Health Sciences;

${ }^{2}$ Shenandoah University; ${ }^{3}$ Larkin University College of Pharmacy; ${ }^{4}$ University of Minnesota College of Pharmacy

\begin{abstract}
Background/Objective(s): Many people in the United States (US) store medications, both prescription and over-the-counter, in their households. They may store medications in a designated location which could pose some convenience for the ease of use and access. However, most people may not know if their medications are stored properly to maintain stability and sterility. The objective of this study is to assess the medication storage locations in US households and evaluate appropriateness for each reported stored medication based on the published literature and drug information databases.
\end{abstract}

Methods: 195 US Qualtrics panel members completed the National Household Medication Survey about medications stored at home and the number of residents in the household. This survey was a cross-sectional, self-administered, online survey completed through Qualtrics. The reported medications and their corresponding storage locations were categorized based on their appropriateness with moisture/humidity, temperatures and accidental exposure to children. The number of medications stored appropriately per household was recorded based on published literature, Lexicomp, Nature Made and Nature's Bounty were consulted.

Results: 154 (79\%) households completed the survey. 75 (38.4\%) households had at least one resident younger than 18 years old. 72 $(46.8 \%)$ households stored at least one medication on a countertop. Only 28 (23.3\%) households stored all their medications appropriately, while 92 (76.7\%) households were storing at least one medication inappropriately. 34 (22\%) households reported medications that were unidentifiable or no medications at all.

457 medications were reported by the 154 households. 13 of the households did not store any medications at home. 162-164 ( 35\%) of the medications were stored appropriately. 52 to 54 ( 11\%) medications had a moisture/humidity issue, 77 to 79 ( 17\%) had a temperature issue, and 42 to 44 ( 9\%) medications had both issues. 23 (5\%) medications had an issue with a potential risk for accidental exposure to children, $6(1.3 \%)$ had issues with both risk for accidental exposure to children and moisture/humidity, 8 (1.8\%) had issues with both risk for accidental exposure to children and temperature, and $4(0.9 \%)$ medications shared all three issues. Some numbers are reported with a range because certain medications have different storage recommendations based on formulation, so if a formulation wasn't specified, both storage recommendations were taken into consideration.

Conclusion: The findings suggest that many US households may be storing medications in inappropriate locations. In order to ensure medication stability and sterility and reduce the risk of accidental ingestion, pharmacists should proactively educate patients on proper storage of their medications and signs of degradation to avoid undesirable effects from the medications.

\section{Background}

Medications stored in households are either in use, unused, unwanted or expired. Law et al. found that every two in three prescription medications stored in United States (US) households were left unused due to side effects, forgetfulness or disease/condition improvement. The total cost of the unused medications in the 306 households studied was estimated to be $\$ 150,000$. 1 I Improper medication storage could be harmful to patients as the medication may have been degraded and can cause undesirable effects upon ingestion.

A few studies have been conducted to investigate how patients store medications at home. Hewson et al. recorded medication storage practices in different households across New Zealand. Along with medication storage, they checked the temperature and humidity of six different storage locations (two bathrooms, one bedroom and three kitchens) in households in two cities.

Corresponding author: Olivia G. Funk, BPS, PharmD Candidate Long Island University

Arnold \& Marie Schwartz College of Pharmacy and Health

Sciences, 1 University Plaza, Brooklyn, NY 11201

Email: olivia.funk@my.liu.edu
Interviews were conducted to record medication storage locations. The bathroom, bedroom and kitchen were the most common locations to store medications. The bathroom had a temperature range of $13.8^{\circ} \mathrm{C}$ to $31.5^{\circ} \mathrm{C}\left(56.8^{\circ} \mathrm{F}-88.7^{\circ} \mathrm{F}\right)$, and a relative humidity range of $33 \%$ to $100 \%$. An ideal storage location should have a temperature range for most medications is from $15^{\circ} \mathrm{C}$ to $30^{\circ} \mathrm{C}\left(59^{\circ} \mathrm{F}-86^{\circ} \mathrm{F}\right)$, and a humidity level below $60 \% .[2,3]$ Bathrooms may be acceptable storage for temperature-sensitive medications in the proper temperature range but may not be good storage for moisture-sensitive medications. The kitchen had a temperature range of 16.0 to $36.3^{\circ} \mathrm{C}\left(60.8^{\circ} \mathrm{F}-97.3^{\circ} \mathrm{F}\right)$, and a relative humidity range of $27.2 \%$ to $85.2 \%$. This finding implies kitchen storage may not be acceptable for both temperature- and humidity-sensitive medications. The bedroom temperatures also ranged from $18.8^{\circ} \mathrm{C}$ to $23.5^{\circ} \mathrm{C}\left(65.8^{\circ} \mathrm{F}-74.3^{\circ} \mathrm{F}\right)$, and the relative humidity ranged between $50.1 \%$ and $69.2 \%$. A bedroom may be an appropriate location for temperature-sensitive medications but may not be for humidity-sensitive medications. Hence, longterm storage of temperature- and humidity-sensitive medications in kitchens or bathrooms should be avoided. Vlieland et al. observed drug storage compliance in 170 geriatric patients. ${ }^{[4]}$ They found that the temperatures in the kitchen ranged from $7.6^{\circ} \mathrm{C}$ to $30.3^{\circ} \mathrm{C}\left(45.7^{\circ} \mathrm{F}-86.5^{\circ} \mathrm{F}\right)$, in the bedroom ranged from $8.4^{\circ} \mathrm{C}$ to $28.6^{\circ} \mathrm{C}\left(47.1^{\circ} \mathrm{F}-83.5^{\circ} \mathrm{F}\right)$ and in the 
bathroom ranged from $10.1^{\circ} \mathrm{C}$ to $24.4^{\circ} \mathrm{C}\left(50.2^{\circ} \mathrm{F}-75.9^{\circ} \mathrm{F}\right)$. This study can imply that temperature-sensitive medications may be at risk of degradation when stored in the kitchen, bedroom or bathroom. $76.4 \%$ of older patients that were evaluated stored all drugs according to recommended storage conditions and $13.6 \%$ of patients stored drugs in a humid or light-exposed location when the package insert recommended otherwise.

Patients should be aware of medication storage recommendations in order to reduce accidental ingestion of a degraded product. A New Zealand study found that medications are stored in areas based on convenience or safety for children. ${ }^{[2]}$ This result shows that few people consider temperature, humidity and light exposure as primary factors for medication storage and may be concerned more with other factors when selecting a storage location.

Medication storage seems to have an impact if there is a minor present in the household. If a child accidentally ingests a medication due to negligence of the storage location, the ingestion could lead to life-threatening consequences. According to the National Capital Poison Center (NCPC), in 2018, children under 12 years of age had the highest rate of unintentional poison exposures. ${ }^{[5]}$ The highest percentage of fatalities of both intentional and unintentional medication exposures was most common in teenagers, nearly $20 \%$ of all exposures had this outcome. It is suspected that the medications are stored in locations that can be easily accessed by children.

If a patient is unsure of how to store their medications, a pharmacist is an easily accessible resource to use to answer questions about proper storage. ${ }^{[6]}$ Other healthcare personnel should develop knowledge about proper storage of medications as well. Many patients may have a nurse who visits their household to help them complete day-to-day activities, including administration of medications. A nurse or caretaker should be mindful of medication storage locations as well ensuring that the medications are properly stored with no signs of degradation.

\section{Study Objective}

The objective of this pilot study is to assess the medication storage locations in households in the United States and evaluate appropriateness for each reported stored medication based on the published literature and drug information databases.

\section{Methods}

The 2018 National Household Medication Inventory Survey was a cross-sectional, self-administered, online survey via Qualtrics. ${ }^{[7]}$ Qualtrics panel member volunteered to complete the survey. 220 households in the United States, between May 2018 to June 2018, were surveyed with 195 households responding to the survey. Each household was surveyed about demographic data, the number of medications being stored in their household, the locations of medication storage, the medication names, and residents in the household (both under 18 years old and over 65 years old). This survey was deemed to be a non-human research and exempt from review by the University of Minnesota Institutional Review Board. The results of this study are based on the findings from the 2018 National Household Medication Survey. Based on the storage recommendations from Lexicomp, Nature Made and Nature's Bounty ${ }^{[8,9,10]}$, the reported medications were categorized into appropriate and inappropriate storage, unknown storage, notapplicable (NA). Inappropriate storage was categorized further into having a "moisture/humidity issue," "temperature issue," "temperature and moisture/humidity issue," "potential risk of accidental exposure to children," "potential risk of accidental exposure to children and temperature issue," "potential risk of accidental exposure to children and moisture/humidity issue" or all three issues. The reported households were also counted based on the number of inappropriately stored medications. Households reporting incomprehensible drug names for all their medications were recorded as "NA."

The kitchen, bathroom and garage are inappropriate storage facilities if a medication requires a tightly controlled temperature. It was assumed for the analysis that garages would undergo constant temperature changes that would be unsuitable for temperature-sensitive medications. If the storage area of an insulin or GLP-1 agonist (e.g., Victoza) was reported to be "other," it was assumed that they were refrigerated and correctly stored since storage recommendations are directly on the box and labeling typically has instructions to refrigerate. When storage was reported as "other," but medications were not accurately specified, the response was categorized as "unknown." Immediate-release (IR) and extended-release (ER) formulations of certain medications have different recommendations for storage and if not specified in the survey response, both formulations were evaluated. Any incomplete responses or unrecognizable names for medications were also recorded as "NA." Medications that should be protected from moisture should be stored in a location with humidity no more than $60 \%$ meaning the bathroom and kitchen were inappropriate for

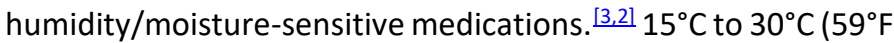
to $86^{\circ} \mathrm{F}$ ) was considered to be adequate since this is the most common storage temperature recommendation based on the literature and Lexicomp. ${ }^{[8]}$ Medications without corresponding storage locations were coded as "unknown." Medications stored on a countertop were considered inappropriate when the household reported to have residents under 18 years old.

The current study assessed the storage location of medications in US households. This outcome was decided based on temperature and humidity recommendations according to the World Health Organization, Lexicomp and literature. While the risk of accidental exposures was evaluated, light exposure risk was not. Light exposure could have a negative impact on medications, but light exposure to medications was not collected in the survey and therefore could not be evaluated. 
Appendix 1 shows the proper medication storage of each drug reported in the survey. The medication storage information was gathered from Lexi-Drugs on Lexicomp, and vitamin storage recommendations were taken from Nature Made or Nature's Bounty storage. Appendix 2 contains the list of medications that lack storage recommendations, were indecipherable or were not specific enough to assign a proper storage recommendation.

\section{Results}

Of the 220 Qualtrics panel members contacted, 195 (89\%) completed the survey, and $25(11.4 \%)$ responses were incomplete. Of the 195, 3 (1.5\%) were not able to accurately follow the survey directions and discontinued.

$79 \%$ of households stored at least 1 medication and $6.7 \%$ of households had no medication stored at home. $79.9 \%$ of households stored 0 to 4 medications, $14.9 \%$ stored 5 to 9 medications and $5.2 \%$ stored over 10 medications. Households stored 3 medications on average, with a minimum of 0 medications and a maximum of 19 medications. A total of $46.8 \%$ households were storing medications on countertops in a bathroom, kitchen or bedroom.

A total of 457 medications were reported with the majority of medications being stored in the kitchen (32.2\%), bathroom
(28.7\%) and bedroom (21.4\%). Table 1 reviews the data overall on storage locations and the number of medications that were being stored in households.

$38.4 \%$ of households had residents under 18 years old and $34.7 \%$ of those households had medications inappropriately stored on countertops where children could easily access them (Table 2).

$23.3 \%$ of households were storing all medications appropriately $76.7 \%$ were storing at least one medication inappropriately. $0.7 \%$ of households were storing 17 medications inappropriately, which was the highest reported number reported in a household. 34 medications' storage was unable to be determined, either due to misspelling or unreadable data (Table 3).

A total of 457 medications were reported. Out of the 457 medications, $35.4 \%$ to $35.9 \%$ medications were stored appropriately. $17.2 \%$ of the medications were either unknown or not applicable in terms of storage. This indicates that the remaining $46.9 \%$ to $47.4 \%$ of medications were stored inappropriately (Table 4). The counts for each category fluctuate due to the difference in storage recommendations between medication formulations.

\begin{tabular}{|c|c|}
\hline \multicolumn{2}{|c|}{ Table 1. Overview Table } \\
\hline Total households & 154 \\
\hline Total medications & 457 \\
\hline Total households not storing medications & 13 \\
\hline \multicolumn{2}{|l|}{ Household storage locations } \\
\hline Kitchen & 147 \\
\hline Bathroom & 131 \\
\hline Bedroom & 98 \\
\hline Utility room & 14 \\
\hline Garage & 5 \\
\hline Hallway closet & 19 \\
\hline Other & 42 \\
\hline No storage location specified & 1 \\
\hline \multicolumn{2}{|l|}{ Medication totals per household } \\
\hline Households with 0-4 medications & 123 \\
\hline Households with 5-9 medications & 23 \\
\hline Households with $10+$ medications & 8 \\
\hline \multicolumn{2}{|l|}{ Household storage } \\
\hline All medications appropriate & 28 \\
\hline 1-4 inappropriately stored medications & 75 \\
\hline 5-9 inappropriately stored medications & 14 \\
\hline $10+$ inappropriately stored medications & 3 \\
\hline Mean medication amount & 2.97 \\
\hline Minimum medications stored & 0 \\
\hline Maximum medications stored & 19 \\
\hline
\end{tabular}




\begin{tabular}{|l|r|}
\hline \multicolumn{2}{|c|}{ Table 2. Households with Minors } \\
\hline Inappropriately Stored & Number of Households \\
\hline Households with residents $\leq 18$ years old & 75 \\
\hline Households storing on countertops (kitchen/bathroom/bedroom) & 72 \\
\hline Households with keep out of reach of children issues & 26 \\
\hline
\end{tabular}

\begin{tabular}{|c|c|}
\hline \multicolumn{2}{|c|}{ Table 3. Storage by Household Medication } \\
\hline Inappropriately Stored & Number of Households \\
\hline All appropriately stored & 28 \\
\hline 1 inappropriately stored & $36(+1)^{*}$ \\
\hline 2 inappropriately stored & $22(+1)^{*}$ \\
\hline 3 inappropriately stored & 9 \\
\hline 4 inappropriately stored & 7 \\
\hline 5 inappropriately stored & $4(+1)^{* *}$ \\
\hline 6 inappropriately stored & $5(+1)^{* *}$ \\
\hline 7 inappropriately stored & 2 \\
\hline 9 inappropriately stored & 2 \\
\hline 10 inappropriately stored & 1 \\
\hline 13 inappropriately stored & 1 \\
\hline 17 inappropriately stored & 1 \\
\hline NA & 34 \\
\hline Total Households Surveyed & 154 \\
\hline Total Households Surveyed (excluding "NA") & 120 \\
\hline $\begin{array}{l}\text { *Oxybutynin was not specified if IR or ER. IR } \\
* * \text { Venlafaxine was not specified in IR tablet, } \\
\text { capsule = moisture/humidity issue }\end{array}$ & = appropriate; ER \\
\hline
\end{tabular}


Table 4. Storage by Individual Medication

\begin{tabular}{|c|c|}
\hline Medication Issue & Number of Medications \\
\hline Appropriate & $162(+2) * / * * *$ \\
\hline Moisture/humidity issue & $52(+2) * / * * *$ \\
\hline Temperature issue & $77(+2) * *$ \\
\hline Temperature \& moisture/humidity issue & $42(+2)^{* *}$ \\
\hline Keep out of reach of children issue & 23 \\
\hline Keep out of reach of children \& moisture/humidity issue & 6 \\
\hline Keep out of reach of children $\&$ temperature issue & 8 \\
\hline Keep out of reach of children, temperature $\&$ moisture/humidity issue & 4 \\
\hline Unknown & 50 \\
\hline NA & 29 \\
\hline Total Medications Counted & 457 \\
\hline \multicolumn{2}{|c|}{$\begin{array}{l}* \text { Oxybutynin was not specified if IR or ER. IR = appropriately; ER = moisture/humidity issue } \\
* * \text { Lovastatin and glipizide were not specified if IR or ER. IR = temperature issue; ER = temperature \& } \\
\text { moisture/humidity issue } \\
* * * \text { Venlafaxine was not specified in IR tablet, ER tablet or ER capsule. IR tablet/ER capsule = appropriate; ER } \\
\text { capsule = moisture/humidity issue }\end{array}$} \\
\hline
\end{tabular}

\section{Discussion}

The results show that many of the medications were stored incorrectly in many US households. Frequently fluctuating temperatures and humidity in kitchens are not optimal storage conditions for either temperature- or humidity-sensitive medications. The current study showed that 147 medications were stored in the kitchen, and most medications have temperature specifications and humidity warnings. It is important for patients to realize the potential risks storing medications in the kitchen and possible negative effects on medication stability. Frequently fluctuating humidity in bedrooms and bathrooms is not ideal for medication storage of humidity-sensitive medications as well. Exposure to high temperatures or humidity should be avoided for long-term storage of medications. Roughly, $30 \%$ of the reported medications had an issue with storage temperatures. Almost a quarter of medications presented with a moisture/humidity issue. Improper medication storage can affect the stability and sterility of a drug, decreasing its potency and effectiveness. Patients should be able to recognize the signs of medication degradation, such as changes in physical appearance or odor. For instance, when aspirin is exposed to excessive humidity it will breakdown into vinegar and salicylic acid. If the degraded tablets are consumed by the patient, it could cause stomach distress, potentially impacting the patient's health. $\frac{[6]}{}$

Medications stored on a counter can be easily accessed by children, and susceptible to their accidental ingestion. In this current study, about $35 \%$ of the households with a minor resident had at least one medication stored on a countertop. Accidental ingestions of medications by children can lead to hospitalizations and possible fatalities. Approximately 60,000 children are brought in to the emergency department each year 
due to medications being stored in reach. $\frac{[11]}{\text { The most common }}$ medications can be toxic to children if taken incorrectly and in higher amounts than recommended.

To ensure stability and sterility of medications, it is important to be mindful of the three factors of medication storage locations. For example, tablets and capsules that are susceptible to heat and moisture should be stored in a location with low heat and moisture and little fluctuations in these factors. Another tip for patients is keeping medications in the original containers, as they provide light resistance and better protection for medications. Pharmacists should educate patients on proper storage of their medications and signs of degradation to avoid sickness and unwanted effects. Pharmacists are one of the most accessible healthcare providers and, according to Gallup's annual survey, are the fourth most trusted profession in 2019. 12$]$ They also have the resources and knowledge about proper medication storage, and can instruct patients on how to properly dispose their unwanted medications. Therefore, pharmacists must intervene and play a larger role in patient medication safety, storage, and disposal education. Some services pharmacists could offer would be free drug disposal services at pharmacies, educating patients about the DEA Drug Take Back Day of drug repository programs or list medications that are on the FDA "flush" list. Medication storage should be a counseling point in every session, even though it may seem like an unimportant point when compared with medication uses, directions and side effects. Improper storage can still pose a negative patient outcome.

Based on the current study, future studies with a larger sample size assessing patient's understanding of medication storage are suggested to be completed. The studies may evaluate the reasons for medication storage location choices and number of expired medications stored at home. Also, a similar study could be conducted with more options for storage locations to ensure more accurate and precise analysis of medication storage locations.

The results from this study don't hold up with what was reported in the article by Vlieland, et al. The study by Vlieland et al., found that more than half of the patients that were evaluated were storing their medications appropriately, however only elderly patients were evaluated. They did not however, have as many options for storage locations as there were in the National Household Medication Survey.

\section{Limitations}

Many participants in this study incorrectly reported the names, formulations and dosages of the medications in their households. If the dosage of the medication was listed in the survey and was specific to one formulation, then that formulation was evaluated. If the formulation could not be determined from the survey response and different formulations had different storage recommendations, both formulations were recorded and included in the analysis. Many people may not realize that storage recommendations vary for each type of formulation and may have assumed that reporting the formulation is unnecessary. Some participants reported whether the medication was a tablet or a cream under the "dose" section, which also hindered deciphering the formulation. Some medications were reported as their nicknames. For instance, "oxy" can mean oxybutynin or oxycodone. Some reported names did not have enough letters to decipher the medication being referring to. Therefore, these medications could not be assessed and were categorized as "NA" (Appendix 2). Survey instructions should be more clear, so they can't be interpreted in different manners. This clarity will ensure patients give the exact information that the researchers are seeking.

In the survey, some other likely storage locations were not available as an option to the participant, such as the refrigerator, living room, car and purse. Medication storage methods, such as prescription bottles, unit dose packs or pill organizers, could have been surveyed, and would be helpful in determining if light-sensitive medications were stored correctly. Light exposure is a major factor to be considered when storing medications, as too much exposure can lead to degradation.

This study generalized the conditions of the storage locations, based on the literature that reported the average temperatures and humidity of certain locations. It is important to note that not all households have the same temperature and humidity levels as others. These variables can change depending on the size of the house, household location, outside weather and number of people in the household. This information could be evaluated and taken into account in future studies to accurately decide if medications are being stored safely and properly.

\section{Conclusion}

Less than half of the patients who participated in the survey were storing their medications appropriately. The fact that many patients are exposing their medications to unacceptable and unstable storage conditions, could implicate a gap where pharmacists could play a large role in which they would have a huge impact. Utilizing the extensive medication knowledge of a pharmacist, accurate storage recommendations could be made to a patient during counseling to ensure the medications are safe from untimely degradation and no undesirable effects are exhibited. 
Acknowledgment: The data collection for this project was funded by the University of Minnesota, College of Pharmacy, Peters Chair in Pharmacy Practice Innovation. The data analysis was supported by the American Association of Colleges of Pharmacy Social and Administrative Sciences Summer 2020 Research Exchange Program; Jon Schommer, PhD, Mentor. We declare no conflicts of interest or financial interests that the authors or members of their immediate families have in any product or service discussed in the manuscript, including grants (pending or received), employment, gifts, stock holdings or options, honoraria, consultancies, expert testimony, patients and royalties.

\section{References}

1. Law AV, Sakharkar P, Zargarzadeh A, et al. Taking stock of medication wastage: Unused medications in US households. Research in Social and Administrative Pharmacy. 2015;11(4):571-578. doi: 10.1016/j.sapharm.2014.10.003

2. Hewson C, Shen CC, Strachan C, Norris P. Personal medicines storage in New Zealand. Journal of Primary Health Care. 2013;5(2):146-150.

3. Guide to good storage practices for pharmaceuticals. World Health Organization. 2003. Accessed July 20, 2020.

4. Vlieland ND, van den Bemt BJF, Bekker CL, Bouvy ML, Egberts TCG, Gardarsdottir H. Older Patients' Compliance with Drug Storage Recommendations. Drugs \& Aging. 2018;35(3):233-241. doi: 10.1007/s40266-018-0524-8.

5. Poison statistics: national data 2018. National Capital Poison Center. https://www.poison.org/poisonstatistics-national. Accessed July 20, 2020.

6. Storing your medications. MedlinePlus Website. https://medlineplus.gov/ency/patientinstructions/00 0534.htm. Accessed August 3, 2020.

7. Dillman, Don A. Mail and Internet Surveys, The Tailored Design Method, 2nd Edition, 2000, John Wiley \& Sons, New York.

8. Lexi-Drugs Online. Hudson $(\mathrm{OH})$ : Lexi-Comp, Inc.;[updated 07/18/2020; accessed 07/20/2020]. http://0online.lexi.com.liucat.lib.liu.edu/lco/action/home.

9. Nature Made prescription label. Pharmavite, LLC., West Hills, CA. https://www.naturemade.com. Accessed July 20, 2020.

10. Nature's Bounty prescription label. Nature's Bounty Co., Holbrook, NY. https://www.naturesbounty.com. Accessed July 20, 2020.

11. The Rise of Medicine in the Home: Implications for Today's Children. Safe Kids Worldwide. https://www.poison.org/ /media/files/pdf-forarticle-dowloads-and-refs/safekids-medicine-safety2016.pdf?la=en. Accessed September 18, 2020.

12. Honesty/Ethics in Profession. Gallup Inc., Washington, D.C. https://news.gallup.com/poll/1654/honesty-ethicsprofessions.aspx. Accessed August 23, 2020. 


\section{Appendix 1}

\begin{tabular}{|c|c|}
\hline Medication & Proper Storage \\
\hline Abilify/Aripiprazole & $\begin{array}{l}\text { Store at } 20^{\circ} \mathrm{C} \text { to } 25^{\circ} \mathrm{C}\left(68^{\circ} \mathrm{F} \text { to } 77^{\circ} \mathrm{F}\right) \text {; excursions permitted to } 15^{\circ} \mathrm{C} \text { to } 30^{\circ} \mathrm{C}\left(59^{\circ} \mathrm{F} \text { to }\right. \\
\left.86^{\circ} \mathrm{F}\right) \text {. Do not store in conditions where tablets are exposed to humid conditions. }\end{array}$ \\
\hline $\begin{array}{l}\text { Acetaminophen/Phenyl } \\
\text { ephrine/Dextromethorp } \\
\text { han }\end{array}$ & Store at room temperature. Protect from excessive heat and moisture. \\
\hline Acetazolamide & Store at controlled room temperature. \\
\hline Adderall & $\begin{array}{l}\text { Extended-release capsules: Store at } 25^{\circ} \mathrm{C}\left(77^{\circ} \mathrm{F}\right) \text {; excursions permitted to } 15^{\circ} \mathrm{C} \text { to } 30^{\circ} \mathrm{C} \\
\left(59^{\circ} \mathrm{F} \text { to } 86^{\circ} \mathrm{F}\right) \text {; protect from light. }\end{array}$ \\
\hline Advair & Store at $20^{\circ} \mathrm{C}$ to $25^{\circ} \mathrm{C}\left(68^{\circ} \mathrm{F}\right.$ to $\left.77^{\circ} \mathrm{F}\right)$. Store in a dry place out of direct heat or sunlight. \\
\hline $\begin{array}{l}\text { Advil } \\
\text { /Motrin/Ibuprofen }\end{array}$ & Store at $20^{\circ} \mathrm{C}$ to $25^{\circ} \mathrm{C}\left(68^{\circ} \mathrm{F}\right.$ to $\left.77^{\circ} \mathrm{F}\right)$ \\
\hline Advil PM/Ibuprofen PM & Store at $20^{\circ} \mathrm{C}$ to $25^{\circ} \mathrm{C}\left(68^{\circ} \mathrm{F}\right.$ to $\left.77^{\circ} \mathrm{F}\right)$; avoid excessive heat. Protect from light. \\
\hline Aleve /Naproxen & Store at $15^{\circ} \mathrm{C}$ to $30^{\circ} \mathrm{C}\left(59^{\circ} \mathrm{F}\right.$ to $\left.86^{\circ} \mathrm{F}\right)$ \\
\hline Allegra/Fexofenadine & Store at $20^{\circ} \mathrm{C}$ to $25^{\circ} \mathrm{C}\left(68^{\circ} \mathrm{F}\right.$ to $\left.77^{\circ} \mathrm{F}\right)$ \\
\hline Allopurinol & Store at $15^{\circ} \mathrm{C}$ to $25^{\circ} \mathrm{C}\left(59^{\circ} \mathrm{F}\right.$ to $\left.77^{\circ} \mathrm{F}\right)$. Store in a dry place. Protect from light. \\
\hline Ambien & IR tablets: Store at $20^{\circ} \mathrm{C}$ to $25^{\circ} \mathrm{C}\left(68^{\circ} \mathrm{F}\right.$ to $\left.77^{\circ} \mathrm{F}\right)$ \\
\hline Amlodipine & Store at $15^{\circ} \mathrm{C}$ to $30^{\circ} \mathrm{C}\left(59^{\circ} \mathrm{F}\right.$ to $\left.86^{\circ} \mathrm{F}\right)$ \\
\hline Amoxicillin & Store at room temperature. \\
\hline Anti-Allergy & Protect from light \\
\hline Apidra & $\begin{array}{l}\text { Stored under refrigeration between } 2^{\circ} \mathrm{C} \text { and } 8^{\circ} \mathrm{C}\left(36^{\circ} \mathrm{F} \text { to } 46^{\circ} \mathrm{F}\right) \text { until the expiration } \\
\text { date or at room temperature for } 28 \text { days; do not freeze; keep away from heat and } \\
\text { sunlight. }\end{array}$ \\
\hline Arava & $\begin{array}{l}\text { Store at } 25^{\circ} \mathrm{C}\left(77^{\circ} \mathrm{F}\right) \text {; excursions permitted to } 15^{\circ} \mathrm{C} \text { to } 30^{\circ} \mathrm{C}\left(59^{\circ} \mathrm{F} \text { to } 86^{\circ} \mathrm{F}\right) \text {. Protect from } \\
\text { light. }\end{array}$ \\
\hline Atenolol & Store at $20^{\circ} \mathrm{C}$ to $25^{\circ} \mathrm{C}\left(68^{\circ} \mathrm{F}\right.$ to $\left.77^{\circ} \mathrm{F}\right)$ \\
\hline Ativan/Lorazepam & Store at $25^{\circ} \mathrm{C}\left(77^{\circ} \mathrm{F}\right)$; excursions are permitted between $15^{\circ} \mathrm{C}$ and $30^{\circ} \mathrm{C}\left(59^{\circ} \mathrm{F}\right.$ and $\left.86^{\circ} \mathrm{F}\right)$. \\
\hline Atomoxetine $\mathrm{HCl}$ & Store at $25^{\circ} \mathrm{C}\left(77^{\circ} \mathrm{F}\right)$; excursions are permitted between $15^{\circ} \mathrm{C}$ and $30^{\circ} \mathrm{C}\left(59^{\circ} \mathrm{F}\right.$ and $\left.86^{\circ} \mathrm{F}\right)$. \\
\hline Atripla & $\begin{array}{l}\text { Store at } 25^{\circ} \mathrm{C}\left(77^{\circ} \mathrm{F}\right) \text {; excursions permitted between } 15^{\circ} \mathrm{C} \text { to } 30^{\circ} \mathrm{C}\left(59^{\circ} \mathrm{F} \text { to } 86^{\circ} \mathrm{F}\right) \text {. } \\
\text { Dispense only in original container. }\end{array}$ \\
\hline Aviane & Store at $20^{\circ} \mathrm{C}$ to $25^{\circ} \mathrm{C}\left(68^{\circ} \mathrm{F}\right.$ to $\left.77^{\circ} \mathrm{F}\right)$ \\
\hline Azithromycin & Store between $15^{\circ} \mathrm{C}$ to $30^{\circ} \mathrm{C}\left(59^{\circ} \mathrm{F}\right.$ to $\left.86^{\circ} \mathrm{F}\right)$. \\
\hline B-12 & 1000mcg soft gels, SL lozenges, Tablets: Store in a cool dry place* \\
\hline Bayer/Aspirin & $\begin{array}{l}\text { Store at room temperature; protect from moisture. Hydrolysis of aspirin occurs upon } \\
\text { exposure to water or moist air, resulting in salicylate and acetate, which possess a } \\
\text { vinegar-like odor. }\end{array}$ \\
\hline
\end{tabular}




\begin{tabular}{|c|c|}
\hline Medication & Proper Storage \\
\hline Benazepril & Store at $\leq 30^{\circ} \mathrm{C}\left(86^{\circ} \mathrm{F}\right)$. Protect from moisture. \\
\hline Bentyl/Dicyclomine & $\begin{array}{l}\text { Store at room temperature, preferably below } 30^{\circ} \mathrm{C}\left(86^{\circ} \mathrm{F}\right) \text {. Protect tablet from direct } \\
\text { sunlight. }\end{array}$ \\
\hline Benzonatate & $\begin{array}{l}\text { Store at } 25^{\circ} \mathrm{C}\left(77^{\circ} \mathrm{F}\right) \text {; excursions permitted between } 15^{\circ} \mathrm{C} \text { to } 30^{\circ} \mathrm{C}\left(59^{\circ} \mathrm{F} \text { to } 86^{\circ} \mathrm{F}\right) \text {. } \\
\text { Protect from light. }\end{array}$ \\
\hline Biotin & Store in a cool, dry place; Store at $59^{\circ} \mathrm{F}-86^{\circ} \mathrm{F}\left(15^{\circ} \mathrm{C}-30^{\circ} \mathrm{C}\right)$ \\
\hline Brillinta & Store at $25^{\circ} \mathrm{C}\left(77^{\circ} \mathrm{F}\right)$; excursions permitted to $15^{\circ} \mathrm{C}$ to $30^{\circ} \mathrm{C}\left(59^{\circ} \mathrm{F}\right.$ to $\left.86^{\circ} \mathrm{F}\right)$. \\
\hline Buspar/Buspirone & $\begin{array}{l}\text { Store at } 20^{\circ} \mathrm{C} \text { to } 25^{\circ} \mathrm{C}\left(68^{\circ} \mathrm{F} \text { to } 77^{\circ} \mathrm{F}\right) \text {; excursions permitted between } 15^{\circ} \mathrm{C} \text { to } 30^{\circ} \mathrm{C}\left(59^{\circ} \mathrm{F}\right. \\
\left.\text { to } 86^{\circ} \mathrm{F}\right) \text {. Protect from light. }\end{array}$ \\
\hline Calcitriol & $\begin{array}{l}\text { Oral capsule, injection, solution: Store at room temperature of } 15^{\circ} \mathrm{C} \text { to } 30^{\circ} \mathrm{C}\left(59^{\circ} \mathrm{F} \text { to }\right. \\
\left.86^{\circ} \mathrm{F}\right) \text {. Protect from light. }\end{array}$ \\
\hline Calcium + Vitamin D* & $600 \mathrm{mg}$ : Store in a cool, dry place* \\
\hline Carbamazepine & $\begin{array}{l}\text { Store at } 20^{\circ} \mathrm{C} \text { to } 25^{\circ} \mathrm{C}\left(68^{\circ} \mathrm{F} \text { to } 77^{\circ} \mathrm{F}\right) \text {; excursions permitted to } 15^{\circ} \mathrm{C} \text { to } 30^{\circ} \mathrm{C}\left(59^{\circ} \mathrm{F} \text { to }\right. \\
\left.86^{\circ} \mathrm{F}\right) \text {; protect from light and moisture. }\end{array}$ \\
\hline Carvedilol & Store at $<30^{\circ} \mathrm{C}\left(<86^{\circ} \mathrm{F}\right)$. Protect from moisture. \\
\hline Celexa/Citalopram & $\begin{array}{l}\text { Store at } 25^{\circ} \mathrm{C}\left(77^{\circ} \mathrm{F}\right) \text {; excursions permitted to } 15^{\circ} \mathrm{C} \text { to } 30^{\circ} \mathrm{C}\left(59^{\circ} \mathrm{F} \text { to } 86^{\circ} \mathrm{F}\right) \text {. Protect from } \\
\text { moisture. }\end{array}$ \\
\hline Chloraseptic & Store at controlled room temperature. Protect from humidity. \\
\hline Cinnamon** & $\begin{array}{l}1000 \mathrm{mg}: \text { store at room temperature** } \\
2000 \mathrm{mg}: \text { store at room temperature**}\end{array}$ \\
\hline Ciprofloxacin & $\begin{array}{l}\text { Store between } 20^{\circ} \mathrm{C} \text { to } 25^{\circ} \mathrm{C}\left(68^{\circ} \mathrm{F} \text { to } 77^{\circ} \mathrm{F}\right) \text {; excursions are permitted between } 15^{\circ} \mathrm{C} \\
\text { and } 30^{\circ} \mathrm{C}\left(59^{\circ} \mathrm{F} \text { and } 86^{\circ} \mathrm{F}\right) .\end{array}$ \\
\hline Claritin/Loratadine & Store at $20^{\circ} \mathrm{C}$ to $25^{\circ} \mathrm{C}\left(68^{\circ} \mathrm{F}\right.$ to $\left.77^{\circ} \mathrm{F}\right)$ \\
\hline Clindamycin & Store at $20^{\circ} \mathrm{C}$ to $25^{\circ} \mathrm{C}\left(68^{\circ} \mathrm{F}\right.$ to $\left.77^{\circ} \mathrm{F}\right)$ \\
\hline Clonidine & $\begin{array}{l}\text { Store at } 25^{\circ} \mathrm{C}\left(77^{\circ} \mathrm{F}\right) \text {; excursions permitted to } 15^{\circ} \mathrm{C} \text { to } 30^{\circ} \mathrm{C}\left(59^{\circ} \mathrm{F} \text { to } 86^{\circ} \mathrm{F}\right) \text {. Protect from } \\
\text { light. }\end{array}$ \\
\hline Clopidogrel & Store at $25^{\circ} \mathrm{C}\left(77^{\circ} \mathrm{F}\right)$; excursions permitted to $15^{\circ} \mathrm{C}$ to $30^{\circ} \mathrm{C}\left(59^{\circ} \mathrm{F}\right.$ to $\left.86^{\circ} \mathrm{F}\right)$. \\
\hline Concerta/Ritalin & $\begin{array}{l}\text { Store at } 25^{\circ} \mathrm{C}\left(77^{\circ} \mathrm{F}\right) \text {; excursions permitted to } 15^{\circ} \mathrm{C} \text { to } 30^{\circ} \mathrm{C}\left(59^{\circ} \mathrm{F} \text { to } 86^{\circ} \mathrm{F}\right) \text {. Protect from } \\
\text { humidity. }\end{array}$ \\
\hline CoQ10 & $\begin{array}{l}100 \mathrm{mg}: \text { store in a cool, dry place* } \\
100 \mathrm{mg} \text { : store at room temperature** }\end{array}$ \\
\hline Cyclobenzaprine & Tablets: Store between $20^{\circ} \mathrm{C}$ and $25^{\circ} \mathrm{C}\left(68^{\circ} \mathrm{F}\right.$ and $\left.77^{\circ} \mathrm{F}\right)$. \\
\hline Cymbalta/Duloxetine & $\begin{array}{l}\text { Store at } 20^{\circ} \mathrm{C} \text { to } 25^{\circ} \mathrm{C}\left(68^{\circ} \mathrm{F} \text { to } 77^{\circ} \mathrm{F}\right) \text {; excursions are permitted between } 15^{\circ} \mathrm{C} \text { and } 30^{\circ} \mathrm{C} \\
\left(59^{\circ} \mathrm{F} \text { and } 86^{\circ} \mathrm{F}\right) .\end{array}$ \\
\hline Dexilant & $\begin{array}{l}\text { Store at } 20^{\circ} \mathrm{C} \text { to } 25^{\circ} \mathrm{C}\left(68^{\circ} \mathrm{F} \text { to } 77^{\circ} \mathrm{F}\right) \text {; excursions are permitted to } 15^{\circ} \mathrm{C} \text { to } 30^{\circ} \mathrm{C}\left(59^{\circ} \mathrm{F} \text { to }\right. \\
\left.86^{\circ} \mathrm{F}\right) \text {. }\end{array}$ \\
\hline
\end{tabular}




\begin{tabular}{|c|c|}
\hline Medication & Proper Storage \\
\hline Dilantin & $\begin{array}{l}\text { Store at } 20^{\circ} \mathrm{C} \text { to } 25^{\circ} \mathrm{C}\left(68^{\circ} \mathrm{F} \text { to } 77^{\circ} \mathrm{F}\right) \text {. Protect capsules from light. Protect capsules from } \\
\text { moisture. }\end{array}$ \\
\hline Diltiazem & $\begin{array}{l}\text { Store at } 25^{\circ} \mathrm{C}\left(77^{\circ} \mathrm{F}\right) \text {; excursions permitted to } 15^{\circ} \mathrm{C} \text { to } 30^{\circ} \mathrm{C}\left(59^{\circ} \mathrm{F} \text { to } 86^{\circ} \mathrm{F}\right) \text {. Protect from } \\
\text { light. Avoid excessive heat }\left(>30^{\circ} \mathrm{C}\right) \text { and humidity. }\end{array}$ \\
\hline Dimetapp & Store at room temperature. \\
\hline Doxycycline & $\begin{array}{l}\text { Store at } 20^{\circ} \mathrm{C} \text { to } 25^{\circ} \mathrm{C}\left(68^{\circ} \mathrm{F} \text { to } 77^{\circ} \mathrm{F}\right) \text {; excursions permitted between } 15^{\circ} \mathrm{C} \text { and } 30^{\circ} \mathrm{C} \\
\left(59^{\circ} \mathrm{F} \text { and } 86^{\circ} \mathrm{F}\right) \text {. Protect from light and moisture. }\end{array}$ \\
\hline Eliquis & $\begin{array}{l}\text { Store at } 20^{\circ} \mathrm{C} \text { to } 25^{\circ} \mathrm{C}\left(68^{\circ} \mathrm{F} \text { to } 77^{\circ} \mathrm{F}\right) \text {; excursions are permitted between } 15^{\circ} \mathrm{C} \text { and } 30^{\circ} \mathrm{C} \\
\left(59^{\circ} \mathrm{F} \text { and } 86^{\circ} \mathrm{F}\right) \text {. }\end{array}$ \\
\hline Enalapril & $\begin{array}{l}\text { Tablet: Store at } 25^{\circ} \mathrm{C}\left(77^{\circ} \mathrm{F}\right) \text {; excursions permitted to } 15^{\circ} \mathrm{C} \text { to } 30^{\circ} \mathrm{C}\left(59^{\circ} \mathrm{F} \text { to } 86^{\circ} \mathrm{F}\right) \text {. } \\
\text { Protect from moisture. }\end{array}$ \\
\hline Enbrel & $\begin{array}{l}\text { Refrigerate at } 2^{\circ} \mathrm{C} \text { to } 8^{\circ} \mathrm{C}\left(36^{\circ} \mathrm{F} \text { to } 46^{\circ} \mathrm{F}\right) \text {. Do not freeze or store in extreme heat or cold. } \\
\text { Individual autoinjectors, prefilled syringes, dose trays, or prefilled pens may be stored } \\
\text { between } 20^{\circ} \mathrm{C} \text { and } 25^{\circ} \mathrm{C}\left(68^{\circ} \mathrm{F} \text { and } 77^{\circ} \mathrm{F}\right) \text { for a maximum single period of } 14 \text { days with } \\
\text { protection from light and sources of heat and humidity. }\end{array}$ \\
\hline Equate Antacid & Store between $15^{\circ} \mathrm{C}$ to $30^{\circ} \mathrm{C}\left(59^{\circ} \mathrm{F}\right.$ to $\left.86^{\circ} \mathrm{F}\right)$. \\
\hline Estarylla & Store at room temperature. Protect from light. \\
\hline Estrofem & Store all products at controlled room temperature. \\
\hline Excedrin & Store at room temperature; protect from light and moisture. \\
\hline Finasteride & Store below $30^{\circ} \mathrm{C}\left(86^{\circ} \mathrm{F}\right)$. Protect from light. Keep container tightly closed. \\
\hline Fish Oil & $\begin{array}{l}\text { Store at } 25^{\circ} \mathrm{C}\left(77^{\circ} \mathrm{F}\right) \text {; excursions are permitted to } 15^{\circ} \mathrm{C} \text { to } 30^{\circ} \mathrm{C}\left(59^{\circ} \mathrm{F} \text { to } 86^{\circ} \mathrm{F}\right) \text {; do not } \\
\text { freeze. }\end{array}$ \\
\hline Flonase/Fluticasone & Store between $4^{\circ} \mathrm{C}$ to $30^{\circ} \mathrm{C}\left(39^{\circ} \mathrm{F}\right.$ to $\left.86^{\circ} \mathrm{F}\right)$. \\
\hline Flovent & $\begin{array}{l}\text { Store between } 20^{\circ} \mathrm{C} \text { and } 25^{\circ} \mathrm{C}\left(68^{\circ} \mathrm{F} \text { and } 77^{\circ} \mathrm{F}\right) \text {; excursions are permitted to } 15^{\circ} \mathrm{C} \text { to } \\
30^{\circ} \mathrm{C}\left(59^{\circ} \mathrm{F} \text { to } 86^{\circ} \mathrm{F}\right) \text {. Do not expose to temperatures greater than } 48.8^{\circ} \mathrm{C}\left(120^{\circ} \mathrm{F}\right) \text {. }\end{array}$ \\
\hline Focalin & $\begin{array}{l}\text { Store at } 20^{\circ} \mathrm{C} \text { to } 25^{\circ} \mathrm{C}\left(68^{\circ} \mathrm{F} \text { to } 77^{\circ} \mathrm{F}\right) \text {; excursions permitted to } 15^{\circ} \mathrm{C} \text { to } 30^{\circ} \mathrm{C}\left(59^{\circ} \mathrm{F} \text { to }\right. \\
\left.86^{\circ} \mathrm{F}\right) \text {. Protect from light and moisture. }\end{array}$ \\
\hline Folic Acid & Store at $20^{\circ} \mathrm{C}$ to $25^{\circ} \mathrm{C}\left(68^{\circ} \mathrm{F}\right.$ to $\left.77^{\circ} \mathrm{F}\right)$; protect from light. \\
\hline Fosamax/Alendronate & $\begin{array}{l}\text { Store at room temperature of } 15^{\circ} \mathrm{C} \text { to } 30^{\circ} \mathrm{C}\left(59^{\circ} \mathrm{F} \text { to } 86^{\circ} \mathrm{F}\right) \text {. Keep in well-closed } \\
\text { container. }\end{array}$ \\
\hline Furosemide & $\begin{array}{l}\text { Store at } 25^{\circ} \mathrm{C}\left(77^{\circ} \mathrm{F}\right) \text {; excursions permitted to } 15^{\circ} \mathrm{C} \text { to } 30^{\circ} \mathrm{C}\left(59^{\circ} \mathrm{F} \text { to } 89^{\circ} \mathrm{F}\right) \text {. Protect from } \\
\text { light. }\end{array}$ \\
\hline Gabapentin & Store at $25^{\circ} \mathrm{C}\left(77^{\circ} \mathrm{F}\right)$; excursions permitted to $15^{\circ} \mathrm{C}$ to $30^{\circ} \mathrm{C}\left(59^{\circ} \mathrm{F}\right.$ to $\left.86^{\circ} \mathrm{F}\right)$. \\
\hline Geodon & Store at $25^{\circ} \mathrm{C}\left(77^{\circ} \mathrm{F}\right)$; excursion permitted to $15^{\circ} \mathrm{C}$ to $30^{\circ} \mathrm{C}\left(59^{\circ} \mathrm{F}\right.$ to $\left.86^{\circ} \mathrm{F}\right)$. \\
\hline Glimepiride & Store at $25^{\circ} \mathrm{C}\left(77^{\circ} \mathrm{F}\right)$; excursions permitted between $20^{\circ} \mathrm{C}$ and $25^{\circ} \mathrm{C}\left(68^{\circ} \mathrm{F}\right.$ and $\left.77^{\circ} \mathrm{F}\right)$ \\
\hline Glipizide & $\begin{array}{l}\text { Extended release: Store at } 68^{\circ} \mathrm{F} \text { to } 77^{\circ} \mathrm{F}\left(20^{\circ} \mathrm{C} \text { to } 25^{\circ} \mathrm{C}\right) \text {; excursions permitted between } \\
59^{\circ} \mathrm{F} \text { to } 86^{\circ} \mathrm{F}\left(15^{\circ} \mathrm{C} \text { to } 30^{\circ} \mathrm{C}\right) \text {. Protect from moisture and humidity. } \\
\text { Immediate release: Store below } 30^{\circ} \mathrm{C}\left(86^{\circ} \mathrm{F}\right) \text {. }\end{array}$ \\
\hline
\end{tabular}




\begin{tabular}{|c|c|}
\hline Medication & Proper Storage \\
\hline Glucosamine & Store at room temperature** \\
\hline Humalog & $\begin{array}{l}\text { Unopened vials, cartridges, and prefilled pens may be stored under refrigeration } \\
\text { between } 2^{\circ} \mathrm{C} \text { and } 8^{\circ} \mathrm{C}\left(36^{\circ} \mathrm{F} \text { to } 46^{\circ} \mathrm{F}\right) \text { until the expiration date or at room temperature } \\
<30^{\circ} \mathrm{C}\left(<86^{\circ} \mathrm{F}\right) \text { for } 28 \text { days; do not freeze; keep away from heat and light. }\end{array}$ \\
\hline Humira & $\begin{array}{l}\text { Store at } 2^{\circ} \mathrm{C} \text { to } 8^{\circ} \mathrm{C}\left(36^{\circ} \mathrm{F} \text { to } 46^{\circ} \mathrm{F}\right) \text { in original container to protect from light; do not } \\
\text { freeze. Do not store in extreme heat or cold. If needed, may be stored at room } \\
\text { temperature up to a maximum of } 25^{\circ} \mathrm{C}\left(77^{\circ} \mathrm{F}\right) \text { for up to } 14 \text { days }\end{array}$ \\
\hline Hydrochlorothiazide & Store at $20^{\circ} \mathrm{C}$ to $25^{\circ} \mathrm{C}\left(68^{\circ} \mathrm{F}\right.$ to $\left.77^{\circ} \mathrm{F}\right)$. Protect from light and moisture. \\
\hline Hydrogen Peroxide & Store at room temperature. \\
\hline Hydroxyzine & Store $<30^{\circ} \mathrm{C}\left(86^{\circ} \mathrm{F}\right)$. Protect from light. \\
\hline Imitrex & $\begin{array}{l}\text { Tablet: Store at } 20^{\circ} \mathrm{C} \text { to } 25^{\circ} \mathrm{C}\left(68^{\circ} \mathrm{F} \text { to } 77^{\circ} \mathrm{F}\right) \text {; excursions are permitted between } 15^{\circ} \mathrm{C} \\
\text { and } 30^{\circ} \mathrm{C}\left(59^{\circ} \mathrm{F} \text { and } 86^{\circ} \mathrm{F}\right) ; \text { do not refrigerate or freeze. }\end{array}$ \\
\hline Iron & (Spring Valley) $27 \mathrm{mg}$ : Store at room temperature $59^{\circ} \mathrm{F}$ and $86^{\circ} \mathrm{F}\left(15^{\circ} \mathrm{C}\right.$ and $\left.30^{\circ} \mathrm{C}\right)$ \\
\hline Isosorbide Mononitrate & $\begin{array}{l}\text { Store at } 25^{\circ} \mathrm{C}\left(77^{\circ} \mathrm{F}\right) \text {; excursions permitted to } 15^{\circ} \mathrm{C} \text { to } 30^{\circ} \mathrm{C}\left(59^{\circ} \mathrm{F} \text { to } 86^{\circ} \mathrm{F}\right) \text {. Protect from } \\
\text { moisture. }\end{array}$ \\
\hline Klonopin/Clonazepam & Store at $20^{\circ} \mathrm{C}$ to $25^{\circ} \mathrm{C}\left(68^{\circ} \mathrm{F}\right.$ to $\left.77^{\circ} \mathrm{F}\right)$. \\
\hline Klor-Con & $\begin{array}{l}\text { Store at } 20^{\circ} \mathrm{C} \text { to } 25^{\circ} \mathrm{C}\left(68^{\circ} \mathrm{F} \text { to } 77^{\circ} \mathrm{F}\right) \text {; excursions permitted to } 15^{\circ} \mathrm{C} \text { to } 30^{\circ} \mathrm{C}\left(59^{\circ} \mathrm{F} \text { to }\right. \\
\left.86^{\circ} \mathrm{F}\right) \text {. Protect from light and moisture. }\end{array}$ \\
\hline Lamotrigine & Store at $15^{\circ} \mathrm{C}$ to $30^{\circ} \mathrm{C}\left(59^{\circ} \mathrm{F}\right.$ to $\left.86^{\circ} \mathrm{F}\right)$. Protect from light. \\
\hline Lantus & $\begin{array}{l}\text { Store unopened vials and prefilled pens refrigerated at } 2^{\circ} \mathrm{C} \text { to } 8^{\circ} \mathrm{C}\left(36^{\circ} \mathrm{F} \text { to } 46^{\circ} \mathrm{F}\right) \text { until } \\
\text { expiration date, or at room temperature }<30^{\circ} \mathrm{C}\left(<86^{\circ} \mathrm{F}\right) \text { for } 28 \text { days; do not freeze; } \\
\text { protect from heat and sunlight. }\end{array}$ \\
\hline Lexapro/Escitalopram & Store at $25^{\circ} \mathrm{C}\left(77^{\circ} \mathrm{F}\right)$; excursions permitted to $15^{\circ} \mathrm{C}$ to $30^{\circ} \mathrm{C}\left(59^{\circ} \mathrm{F}\right.$ to $\left.86^{\circ} \mathrm{F}\right)$. \\
\hline Librax & Store at $25^{\circ} \mathrm{C}\left(77^{\circ} \mathrm{F}\right)$; excursions permitted to $15^{\circ} \mathrm{C}$ to $30^{\circ} \mathrm{C}\left(59^{\circ} \mathrm{F}\right.$ to $\left.86^{\circ} \mathrm{F}\right)$. \\
\hline Lipitor/Atorvastatin & Store at $20^{\circ} \mathrm{C}$ to $25^{\circ} \mathrm{C}\left(68^{\circ} \mathrm{F}\right.$ to $\left.77^{\circ} \mathrm{F}\right)$. \\
\hline Lisinopril & Store at $15^{\circ} \mathrm{C}$ to $30^{\circ} \mathrm{C}\left(59^{\circ} \mathrm{F}\right.$ to $\left.86^{\circ} \mathrm{F}\right)$. Protect from moisture. \\
\hline Lithium & $\begin{array}{l}\text { Store between } 15^{\circ} \mathrm{C} \text { and } 30^{\circ} \mathrm{C}\left(59^{\circ} \mathrm{F} \text { to } 86^{\circ} \mathrm{F}\right) \text {. Protect tablets and capsules from } \\
\text { moisture. }\end{array}$ \\
\hline Losartan & $\begin{array}{l}\text { Store at } 25^{\circ} \mathrm{C}\left(77^{\circ} \mathrm{F}\right) \text {; excursions are permitted to } 15^{\circ} \mathrm{C} \text { to } 30^{\circ} \mathrm{C}\left(59^{\circ} \mathrm{F} \text { to } 86^{\circ} \mathrm{F}\right) \text {. Protect } \\
\text { from light. }\end{array}$ \\
\hline Lovastatin & $\begin{array}{l}\text { Immediate release: Store at } 20^{\circ} \mathrm{C} \text { to } 25^{\circ} \mathrm{C}\left(68^{\circ} \mathrm{F} \text { to } 77^{\circ} \mathrm{F}\right) \text {. Protect from light } \\
\text { Extended release: Store at } 20^{\circ} \mathrm{C} \text { to } 25^{\circ} \mathrm{C}\left(68^{\circ} \mathrm{F} \text { to } 77^{\circ} \mathrm{F}\right) \text {; excursions permitted between } \\
15^{\circ} \mathrm{C} \text { to } 30^{\circ} \mathrm{C}\left(59^{\circ} \mathrm{F} \text { to } 86^{\circ} \mathrm{F}\right) \text {. Avoid excessive heat and humidity. }\end{array}$ \\
\hline Lyrica & $\begin{array}{l}\text { Store at } 20^{\circ} \mathrm{C} \text { to } 25^{\circ} \mathrm{C}\left(68^{\circ} \mathrm{F} \text { to } 77^{\circ} \mathrm{F}\right) \text {; excursions permitted to } 15^{\circ} \mathrm{C} \text { to } 30^{\circ} \mathrm{C}\left(59^{\circ} \mathrm{F} \text { to }\right. \\
\left.86^{\circ} \mathrm{F}\right) \text {. }\end{array}$ \\
\hline Magnesium & Store at controlled room temperature. Protect from moisture. \\
\hline Melatonin & Store at room temperature and avoid excessive heat \\
\hline
\end{tabular}




\begin{tabular}{|c|c|}
\hline Medication & Proper Storage \\
\hline Meloxicam & $\begin{array}{l}\text { Store at } 25^{\circ} \mathrm{C}\left(77^{\circ} \mathrm{F}\right) \text {; excursions permitted to } 15^{\circ} \mathrm{C} \text { to } 30^{\circ} \mathrm{C}\left(59^{\circ} \mathrm{F} \text { to } 86^{\circ} \mathrm{F}\right) \text {. Protect } \\
\text { tablets and capsules from moisture. }\end{array}$ \\
\hline Metamucil & Store at room temperature; protect from moisture \\
\hline Metformin & $\begin{array}{l}\text { Store at } 20^{\circ} \mathrm{C} \text { to } 25^{\circ} \mathrm{C}\left(68^{\circ} \mathrm{F} \text { to } 77^{\circ} \mathrm{F}\right) \text {; excursion permitted to } 15^{\circ} \mathrm{C} \text { to } 30^{\circ} \mathrm{C}\left(59^{\circ} \mathrm{F} \text { to }\right. \\
\left.86^{\circ} \mathrm{F}\right) \text {. Protect from light and moisture. }\end{array}$ \\
\hline Methotrexate & Store between $20^{\circ} \mathrm{C}$ and $25^{\circ} \mathrm{C}\left(68^{\circ} \mathrm{F}\right.$ and $\left.77^{\circ} \mathrm{F}\right)$. Protect from light. \\
\hline Metoprolol Succinate & $\begin{array}{l}\text { Store at } 25^{\circ} \mathrm{C}\left(77^{\circ} \mathrm{F}\right) \text {; excursions permitted to } 15^{\circ} \mathrm{C} \text { to } 30^{\circ} \mathrm{C}\left(59^{\circ} \mathrm{F} \text { to } 86^{\circ} \mathrm{F}\right) \text {. Protect from } \\
\text { moisture. }\end{array}$ \\
\hline Metoprolol Tartrate & $\begin{array}{l}\text { Store at } 25^{\circ} \mathrm{C}\left(77^{\circ} \mathrm{F}\right) \text {; excursions permitted to } 15^{\circ} \mathrm{C} \text { to } 30^{\circ} \mathrm{C}\left(59^{\circ} \mathrm{F} \text { to } 86^{\circ} \mathrm{F}\right) \text {. Protect from } \\
\text { moisture. }\end{array}$ \\
\hline Metronidazole & Store at $15^{\circ} \mathrm{C}$ to $25^{\circ} \mathrm{C}\left(59^{\circ} \mathrm{F}\right.$ to $\left.77^{\circ} \mathrm{F}\right)$. Protect the tablets from light. \\
\hline Microgestin & Store at controlled room temperature. \\
\hline Mirtazepine/Remeron & $\begin{array}{l}\text { Store at } 20^{\circ} \mathrm{C} \text { to } 25^{\circ} \mathrm{C}\left(68^{\circ} \mathrm{F} \text { to } 77^{\circ} \mathrm{F}\right) \text {; excursions are permitted between } 15^{\circ} \mathrm{C} \text { and } 30^{\circ} \mathrm{C} \\
\left(59^{\circ} \mathrm{F} \text { and } 86^{\circ} \mathrm{F}\right) \text {. Protect from light and moisture. }\end{array}$ \\
\hline Mucus Relief & Store at room temperature; do not refrigerate. Protect from light. \\
\hline Nasacort & Store at $20^{\circ} \mathrm{C}$ to $25^{\circ} \mathrm{C}\left(68^{\circ} \mathrm{F}\right.$ to $\left.77^{\circ} \mathrm{F}\right)$; do not freeze. \\
\hline Nexium & Store at $25^{\circ} \mathrm{C}\left(77^{\circ} \mathrm{F}\right)$; excursions permitted to $15^{\circ} \mathrm{C}$ to $30^{\circ} \mathrm{C}\left(59^{\circ} \mathrm{F}\right.$ to $\left.86^{\circ} \mathrm{F}\right)$. \\
\hline Niacin & Store at room temperature. \\
\hline Nifedipine & $\begin{array}{l}\text { Store below } 30^{\circ} \mathrm{C}\left(86^{\circ} \mathrm{F}\right) \text {; protect from light and moisture. excursions permitted to } \\
15^{\circ} \mathrm{C} \text { to } 30^{\circ} \mathrm{C}\left(59^{\circ} \mathrm{F} \text { to } 86^{\circ} \mathrm{F}\right)\end{array}$ \\
\hline $\begin{array}{l}\text { Nite } \\
\text { Time/Nyquil/Dextromet } \\
\text { horphan/Doxylamine } \\
\text { succinate }\end{array}$ & Store at room temperature. \\
\hline Norco & Store at $20^{\circ} \mathrm{C}$ to $25^{\circ} \mathrm{C}\left(68^{\circ} \mathrm{F}\right.$ to $\left.77^{\circ} \mathrm{F}\right)$. Protect from light. \\
\hline Olmesartan & Store at $20^{\circ} \mathrm{C}$ to $25^{\circ} \mathrm{C}\left(68^{\circ} \mathrm{F}\right.$ to $\left.77^{\circ} \mathrm{F}\right)$. \\
\hline Omeprazole & $\begin{array}{l}\text { Capsules, tablets: Store at } 15^{\circ} \mathrm{C} \text { to } 30^{\circ} \mathrm{C}\left(59^{\circ} \mathrm{F} \text { to } 86^{\circ} \mathrm{F}\right) \text {. Protect from light and moisture. } \\
\text { OTC capsules: Store at } 20^{\circ} \mathrm{C} \text { to } 25^{\circ} \mathrm{C}\left(68^{\circ} \mathrm{F} \text { to } 77^{\circ} \mathrm{F}\right) \text {; protect from moisture. }\end{array}$ \\
\hline $\begin{array}{l}\text { One A Day Women's } \\
\text { Multivitamin }\end{array}$ & Store at room temperature; avoid excessive heat above $40^{\circ} \mathrm{C}\left(104^{\circ} \mathrm{F}\right)$ \\
\hline Onglyza & $\begin{array}{l}\text { Store at } 20^{\circ} \mathrm{C} \text { to } 25^{\circ} \mathrm{C}\left(68^{\circ} \mathrm{F} \text { to } 77^{\circ} \mathrm{F}\right) \text {; excursions permitted between } 15^{\circ} \mathrm{C} \text { to } 30^{\circ} \mathrm{C}\left(59^{\circ} \mathrm{F}\right. \\
\left.\text { to } 86^{\circ} \mathrm{F}\right) .\end{array}$ \\
\hline Oxybutynin & $\begin{array}{l}\text { Immediate release tablet and syrup: Store at } 20^{\circ} \mathrm{C} \text { to } 25^{\circ} \mathrm{C}\left(68^{\circ} \mathrm{F} \text { to } 77^{\circ} \mathrm{F}\right) \text {. Protect from } \\
\text { light. } \\
\text { Extended release tablet: Store at } 25^{\circ} \mathrm{C}\left(77^{\circ} \mathrm{F}\right) \text {; excursions permitted to } 15^{\circ} \mathrm{C} \text { to } 30^{\circ} \mathrm{C} \\
\left(59^{\circ} \mathrm{F} \text { to } 86^{\circ} \mathrm{F}\right) \text {. Protect from moisture and humidity. }\end{array}$ \\
\hline Oxycodone & $\begin{array}{l}\text { Store at } 25^{\circ} \mathrm{C}\left(77^{\circ} \mathrm{F}\right) \text {; excursions permitted between } 15^{\circ} \mathrm{C} \text { to } 30^{\circ} \mathrm{C}\left(59^{\circ} \mathrm{F} \text { to } 86^{\circ} \mathrm{F}\right) \text {. } \\
\text { Protect from light and moisture. }\end{array}$ \\
\hline
\end{tabular}




\begin{tabular}{|c|c|}
\hline Medication & Proper Storage \\
\hline Paxil/Paroxetine & $\begin{array}{l}\text { Tablets: Store between } 20^{\circ} \mathrm{C} \text { and } 25^{\circ} \mathrm{C}\left(68^{\circ} \mathrm{F} \text { and } 77^{\circ} \mathrm{F}\right) \text {; excursions permitted between } \\
15^{\circ} \mathrm{C} \text { and } 30^{\circ} \mathrm{C}\left(59^{\circ} \mathrm{F} \text { and } 86^{\circ} \mathrm{F}\right) .\end{array}$ \\
\hline Penicillin & Store at $20^{\circ} \mathrm{C}$ to $25^{\circ} \mathrm{C}\left(68^{\circ} \mathrm{F}\right.$ to $\left.77^{\circ} \mathrm{F}\right)$. \\
\hline Pepto Bismol & Store at room temperature. Avoid excessive heat. Protect from freezing. \\
\hline Phenobarbital & Store between $20^{\circ} \mathrm{C}$ and $25^{\circ} \mathrm{C}\left(68^{\circ} \mathrm{F}\right.$ and $\left.77^{\circ} \mathrm{F}\right)$. Protect from light. \\
\hline Phentermine & Store at $20^{\circ} \mathrm{C}$ to $25^{\circ} \mathrm{C}\left(68^{\circ} \mathrm{F}\right.$ to $\left.77^{\circ} \mathrm{F}\right)$. \\
\hline PNV & Room temperature, avoid excessive heat \\
\hline Polyethylene Glycol & $\begin{array}{l}\text { Store at } 20^{\circ} \mathrm{C} \text { to } 25^{\circ} \mathrm{C}\left(68^{\circ} \mathrm{F} \text { to } 77^{\circ} \mathrm{F}\right) \text {; excursions are permitted between } 15^{\circ} \mathrm{C} \text { to } 30^{\circ} \mathrm{C} \\
\left(59^{\circ} \mathrm{F} \text { to } 86^{\circ} \mathrm{F}\right) .\end{array}$ \\
\hline Pravastatin & $\begin{array}{l}\text { Store at } 25^{\circ} \mathrm{C}\left(77^{\circ} \mathrm{F}\right) \text {; excursions permitted to } 15^{\circ} \mathrm{C} \text { to } 30^{\circ} \mathrm{C}\left(59^{\circ} \mathrm{F} \text { to } 86^{\circ} \mathrm{F}\right) \text {. Protect from } \\
\text { light. }\end{array}$ \\
\hline Prednisone & $\begin{array}{l}\text { Store at } 25^{\circ} \mathrm{C}\left(77^{\circ} \mathrm{F}\right) \text {; excursions permitted to } 15^{\circ} \mathrm{C} \text { to } 30^{\circ} \mathrm{C}\left(59^{\circ} \mathrm{F} \text { to } 86^{\circ} \mathrm{F}\right) \text {. Protect from } \\
\text { light and moisture. }\end{array}$ \\
\hline Propranolol & $\begin{array}{l}\text { Store at controlled room temperature; protect from freezing or excessive heat. } \\
\text { Protect from light and moisture. }\end{array}$ \\
\hline Prozac/Fluoxetine & All dosage forms should be stored at controlled room temperature. Protect from light. \\
\hline Quetiapine & Store at $25^{\circ} \mathrm{C}\left(77^{\circ} \mathrm{F}\right)$; excursions permitted between $15^{\circ} \mathrm{C}$ and $30^{\circ} \mathrm{C}\left(59^{\circ} \mathrm{F}\right.$ and $\left.86^{\circ} \mathrm{F}\right)$. \\
\hline Refresh & Store at $59^{\circ} \mathrm{F}$ and $86^{\circ} \mathrm{F}\left(15^{\circ} \mathrm{C}\right.$ and $\left.30^{\circ} \mathrm{C}\right)$ \\
\hline Remicade & $\begin{array}{l}\text { Store intact vials at } 2^{\circ} \mathrm{C} \text { to } 8^{\circ} \mathrm{C}\left(36^{\circ} \mathrm{F} \text { to } 46^{\circ} \mathrm{F}\right) \text {; may be stored at room temperature } \\
\text { (maximum of } 30^{\circ} \mathrm{C}\left[86^{\circ} \mathrm{F}\right] \text { ) for up to } 6 \text { months (not to exceed the original expiration } \\
\text { date); do not return to refrigerated storage. }\end{array}$ \\
\hline Risperidone & Store at $15^{\circ} \mathrm{C}$ to $25^{\circ} \mathrm{C}\left(59^{\circ} \mathrm{F}\right.$ to $\left.77^{\circ} \mathrm{F}\right)$. Protect from light and moisture. \\
\hline Rosuvastatin & Tablet: Store between $20^{\circ} \mathrm{C}$ and $25^{\circ} \mathrm{C}\left(68^{\circ} \mathrm{F}\right.$ to $\left.77^{\circ} \mathrm{F}\right)$. Protect from moisture. \\
\hline Senexon/Senna-lax & $\begin{array}{l}\text { Store at } 20^{\circ} \mathrm{C} \text { to } 25^{\circ} \mathrm{C}\left(77^{\circ} \mathrm{F}\right) \text {; excursions are permitted between } 15^{\circ} \mathrm{C} \text { and } 30^{\circ} \mathrm{C}\left(59^{\circ} \mathrm{F} \text { to }\right. \\
\left.86^{\circ} \mathrm{F}\right) \text {. }\end{array}$ \\
\hline Simethicone & $\begin{array}{l}\text { Store at } 20^{\circ} \mathrm{C} \text { to } 25^{\circ} \mathrm{C}\left(68^{\circ} \mathrm{F} \text { to } 77^{\circ} \mathrm{F}\right) \text {. Protect from moisture. Avoid high humidity and } \\
\text { excessive heat. }\end{array}$ \\
\hline $\begin{array}{l}\text { Simply } \\
\text { Sleep/Benadryl/Allergy } \\
\text { Relief }\end{array}$ & Store at room temperature. Protect capsules and tablets from moisture. \\
\hline Simvastatin & Store at $5^{\circ} \mathrm{C}$ to $30^{\circ} \mathrm{C}\left(41^{\circ} \mathrm{F}\right.$ to $\left.86^{\circ} \mathrm{F}\right)$ \\
\hline Singulair & $\begin{array}{l}\text { Store at } 20^{\circ} \mathrm{C} \text { to } 25^{\circ} \mathrm{C}\left(68^{\circ} \mathrm{F} \text { to } 77^{\circ} \mathrm{F}\right) \text {; excursions permitted to } 15^{\circ} \mathrm{C} \text { to } 30^{\circ} \mathrm{C}\left(59^{\circ} \mathrm{F} \text { to }\right. \\
\left.86^{\circ} \mathrm{F}\right) \text {. Protect from moisture and light. }\end{array}$ \\
\hline Sinus Relief & Store at $20^{\circ} \mathrm{C}$ to $25^{\circ} \mathrm{C}\left(68^{\circ} \mathrm{F}\right.$ to $\left.77^{\circ} \mathrm{F}\right)$. \\
\hline Sleep Aid & Store at $20^{\circ} \mathrm{C}$ to $25^{\circ} \mathrm{C}\left(68^{\circ} \mathrm{F}\right.$ to $\left.77^{\circ} \mathrm{F}\right)$ \\
\hline Sotalol & Store at $25^{\circ} \mathrm{C}\left(77^{\circ} \mathrm{F}\right)$; excursions permitted between $15^{\circ} \mathrm{C}$ and $30^{\circ} \mathrm{C}\left(59^{\circ} \mathrm{F}\right.$ and $\left.86^{\circ} \mathrm{F}\right)$. \\
\hline
\end{tabular}




\begin{tabular}{|c|c|}
\hline Medication & Proper Storage \\
\hline Spironolactone & Store below $25^{\circ} \mathrm{C}\left(77^{\circ} \mathrm{F}\right)$. \\
\hline Starlix & Store at $25^{\circ} \mathrm{C}\left(77^{\circ} \mathrm{F}\right)$; excursions are permitted between $15^{\circ} \mathrm{C}$ and $30^{\circ} \mathrm{C}\left(59^{\circ} \mathrm{F}\right.$ and $\left.86^{\circ} \mathrm{F}\right)$. \\
\hline $\begin{array}{l}\text { Synthroid/Levothyroxin } \\
\text { e/Levoxyl }\end{array}$ & $\begin{array}{l}\text { Store at } 25^{\circ} \mathrm{C}\left(77^{\circ} \mathrm{F}\right) \text {; excursions are permitted between } 15^{\circ} \mathrm{C} \text { and } 30^{\circ} \mathrm{C}\left(59^{\circ} \mathrm{F} \text { and } 86^{\circ} \mathrm{F}\right) \text {. } \\
\text { Protect from heat, light, and moisture. }\end{array}$ \\
\hline Tizanidine & Store at $25^{\circ} \mathrm{C}\left(77^{\circ} \mathrm{F}\right)$; excursions are permitted between $15^{\circ} \mathrm{C}$ and $30^{\circ} \mathrm{C}\left(59^{\circ} \mathrm{F}\right.$ and $\left.86^{\circ} \mathrm{F}\right)$. \\
\hline Tradjenta & $\begin{array}{l}\text { Store at } 20^{\circ} \mathrm{C} \text { to } 25^{\circ} \mathrm{C}\left(68^{\circ} \mathrm{F} \text { to } 77^{\circ} \mathrm{F}\right) \text {; excursions permitted between } 15^{\circ} \mathrm{C} \text { to } 30^{\circ} \mathrm{C}\left(59^{\circ} \mathrm{F}\right. \\
\left.\text { to } 86^{\circ} \mathrm{F}\right) \text {. }\end{array}$ \\
\hline Tramadol & $\begin{array}{l}\text { Store at } 20^{\circ} \mathrm{C} \text { to } 25^{\circ} \mathrm{C}\left(68^{\circ} \mathrm{F} \text { to } 77^{\circ} \mathrm{F}\right) \text {; excursions permitted to } 15^{\circ} \mathrm{C} \text { to } 30^{\circ} \mathrm{C}\left(59^{\circ} \mathrm{F} \text { to }\right. \\
\left.86^{\circ} \mathrm{F}\right) \text {. }\end{array}$ \\
\hline Trazodone & 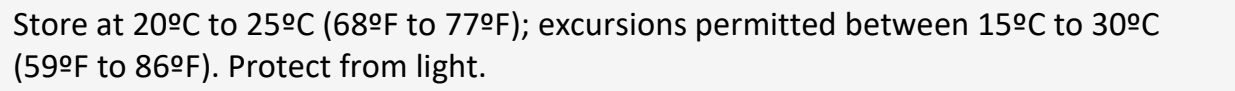 \\
\hline Triamcinolone & Cream: Store at $20^{\circ} \mathrm{C}$ to $25^{\circ} \mathrm{C}\left(68^{\circ} \mathrm{F}\right.$ to $\left.77^{\circ} \mathrm{F}\right)$ \\
\hline Trilipix/Fenofibrate & $\begin{array}{l}\text { Store at } 25^{\circ} \mathrm{C}\left(77^{\circ} \mathrm{F}\right) \text {; excursions are permitted between } 15^{\circ} \mathrm{C} \text { and } 30^{\circ} \mathrm{C}\left(59^{\circ} \mathrm{F} \text { and } 86^{\circ} \mathrm{F}\right) \text {. } \\
\text { Protect TriCor from moisture. }\end{array}$ \\
\hline Tylenol/Acetaminophen & Store at $20^{\circ} \mathrm{C}$ to $25^{\circ} \mathrm{C}\left(68^{\circ} \mathrm{F}\right.$ to $\left.77^{\circ} \mathrm{F}\right)$; avoid excessive heat $\left(40^{\circ} \mathrm{C}\left[104^{\circ} \mathrm{F}\right]\right)$. \\
\hline Tylenol PM & Store at $20^{\circ} \mathrm{F}$ and $25^{\circ} \mathrm{F}\left(68^{\circ} \mathrm{C}\right.$ and $\left.77^{\circ} \mathrm{C}\right)$ \\
\hline Vaniqa & $\begin{array}{l}\text { Store at controlled room temperature } 25^{\circ} \mathrm{C}\left(77^{\circ} \mathrm{F}\right) \text {; excursions permitted to } 15^{\circ} \mathrm{C} \text { to } \\
30^{\circ} \mathrm{C}\left(59^{\circ} \mathrm{F} \text { to } 86^{\circ} \mathrm{F}\right) \text {; do not freeze. }\end{array}$ \\
\hline Venlafaxine/Effexor & $\begin{array}{l}\text { Immediate-release tablets and extended-release capsules: Store at } 20^{\circ} \mathrm{C} \text { to } 25^{\circ} \mathrm{C}\left(68^{\circ} \mathrm{F}\right. \\
\left.\text { to } 77^{\circ} \mathrm{F}\right) \text {. } \\
\text { Extended-release tablets: Store at } 25^{\circ} \mathrm{C}\left(77^{\circ} \mathrm{F}\right) \text {; excursions permitted between } 15^{\circ} \mathrm{C} \\
\text { and } 30^{\circ} \mathrm{C}\left(59^{\circ} \mathrm{F} \text { and } 86^{\circ} \mathrm{F}\right) \text {. Protect from moisture and humidity. }\end{array}$ \\
\hline Ventolin/ProAir & $\begin{array}{l}\text { Metered-dose inhalers (HFA aerosols): Store at } 15^{\circ} \mathrm{C} \text { to } 25^{\circ} \mathrm{C}\left(59^{\circ} \mathrm{F} \text { to } 77^{\circ} \mathrm{F}\right) \text {. Do not } \\
\text { store at temperature }>120^{\circ} \mathrm{F} \text {. Do not puncture. Do not use or store near heat or open } \\
\text { flame. }\end{array}$ \\
\hline Verapamil & $\begin{array}{l}\text { Calan SR (tab): Store at } 15^{\circ} \mathrm{C} \text { to } 25^{\circ} \mathrm{C}\left(59^{\circ} \mathrm{F} \text { to } 77^{\circ} \mathrm{F}\right) \text {. Protect from light and moisture. } \\
\text { Verelan (cap): Store at } 20^{\circ} \mathrm{C} \text { to } 25^{\circ} \mathrm{C}\left(68^{\circ} \mathrm{F} \text { to } 77^{\circ} \mathrm{F}\right) \text {. Avoid excessive heat; protect from } \\
\text { moisture. Brief temperature }>25^{\circ} \mathrm{C}\left(77^{\circ} \mathrm{F}\right) \text { should be avoided. }\end{array}$ \\
\hline Vesicare & Store at $25^{\circ} \mathrm{C}\left(77^{\circ} \mathrm{F}\right)$; excursions permitted to $15^{\circ} \mathrm{C}$ to $30^{\circ} \mathrm{C}\left(59^{\circ} \mathrm{F}\right.$ to $\left.86^{\circ} \mathrm{F}\right)$. \\
\hline Vicodin & Store at $20^{\circ} \mathrm{C}$ to $25^{\circ} \mathrm{C}\left(68^{\circ} \mathrm{F}\right.$ to $\left.77^{\circ} \mathrm{F}\right)$. Protect from light. \\
\hline Victoza & $\begin{array}{l}\text { Prior to initial use, store at } 2^{\circ} \mathrm{C} \text { to } 8^{\circ} \mathrm{C}\left(36^{\circ} \mathrm{F} \text { to } 46^{\circ} \mathrm{F}\right) \text {; after initial use, may be stored at } \\
2^{\circ} \mathrm{C} \text { to } 8^{\circ} \mathrm{C}\left(36^{\circ} \mathrm{F} \text { to } 46^{\circ} \mathrm{F}\right) \text { or at } 15^{\circ} \mathrm{C} \text { to } 30^{\circ} \mathrm{C}\left(59^{\circ} \mathrm{F} \text { to } 86^{\circ} \mathrm{F}\right) \text {. Do not freeze or store } \\
\text { directly adjacent to the refrigerator cooling element. Protect from heat and light. }\end{array}$ \\
\hline Vitamin C & Store at room temperature. \\
\hline $\begin{array}{l}\text { Vitamin D/Vitamin D3 } \\
\text { Cholecalciferol D3 }\end{array}$ & Store at $15^{\circ} \mathrm{C}$ to $30^{\circ} \mathrm{C}\left(59^{\circ} \mathrm{F}\right.$ to $\left.86^{\circ} \mathrm{F}\right)$; do not freeze. Protect from light. \\
\hline Vivelle-Dot Patch & Store in protective pouch. \\
\hline Warfarin & Store at $15^{\circ} \mathrm{C}$ to $30^{\circ} \mathrm{C}\left(59^{\circ} \mathrm{F}\right.$ to $\left.86^{\circ} \mathrm{F}\right)$. Protect from light. \\
\hline
\end{tabular}




\begin{tabular}{|c|c|}
\hline Medication & Proper Storage \\
\hline Wellbutrin & Store at $15^{\circ} \mathrm{C}$ to $30^{\circ} \mathrm{C}\left(59^{\circ} \mathrm{F}\right.$ to $\left.86^{\circ} \mathrm{F}\right)$. Protect from light and moisture. \\
\hline Xanax/Alprazolam & Store at $20^{\circ} \mathrm{C}$ to $25^{\circ} \mathrm{C}\left(68^{\circ} \mathrm{F}\right.$ to $\left.77^{\circ} \mathrm{F}\right)$. \\
\hline Xyzal & Store at $20^{\circ} \mathrm{C}$ to $25^{\circ} \mathrm{C}\left(68^{\circ} \mathrm{F}\right.$ to $\left.77^{\circ} \mathrm{F}\right)$ \\
\hline Yosprala & $\begin{array}{l}\text { Store at } 25^{\circ} \mathrm{C}\left(77^{\circ} \mathrm{F}\right) \text {; excursions permitted to } 15^{\circ} \mathrm{C} \text { to } 30^{\circ} \mathrm{C}\left(59^{\circ} \mathrm{F} \text { to } 86^{\circ} \mathrm{F}\right) \text {. Store in } \\
\text { original container. Protect from moisture. }\end{array}$ \\
\hline Zantac & $\begin{array}{l}\text { Store between } 20^{\circ} \mathrm{C} \text { and } 25^{\circ} \mathrm{C}\left(68^{\circ} \mathrm{F} \text { and } 77^{\circ} \mathrm{F}\right) \text {. Protect from light. Protect from } \\
\text { moisture. }\end{array}$ \\
\hline Zoloft/Sertraline & $\begin{array}{l}\text { Store at } 20^{\circ} \mathrm{C} \text { to } 25^{\circ} \mathrm{C}\left(68^{\circ} \mathrm{F} \text { to } 77^{\circ} \mathrm{F}\right) \text {; excursions permitted to } 15^{\circ} \mathrm{C} \text { to } 30^{\circ} \mathrm{C}\left(59^{\circ} \mathrm{F} \text { to }\right. \\
\left.86^{\circ} \mathrm{F}\right) \text {. }\end{array}$ \\
\hline Zonegran/Zonisamide & $\begin{array}{l}\text { Store at } 25^{\circ} \mathrm{C}\left(77^{\circ} \mathrm{F}\right) \text { excursions are permitted between } 15^{\circ} \mathrm{C} \text { and } 30^{\circ} \mathrm{C}\left(59^{\circ} \mathrm{F} \text { and } 86^{\circ} \mathrm{F}\right) \text {. } \\
\text { Protect from moisture and light. }\end{array}$ \\
\hline Zyrtec/Wal-zyr & $\begin{array}{l}\text { Store at } 20^{\circ} \mathrm{C} \text { to } 25^{\circ} \mathrm{C}\left(68^{\circ} \mathrm{F} \text { to } 77^{\circ} \mathrm{F}\right) \text {; excursions are permitted between } 15^{\circ} \mathrm{C} \text { and } 30^{\circ} \mathrm{C} \\
\left(59^{\circ} \mathrm{F} \text { and } 86^{\circ} \mathrm{F}\right) .\end{array}$ \\
\hline \multicolumn{2}{|c|}{$\begin{array}{l}\text { All medication information was gathered from Lexi-drugs via Lexicomp drug information database } \\
\text { * Retrieved from Nature Made prescription label[9] } \\
\text { * Retrieved from Nature's Bounty prescription label[10] }\end{array}$} \\
\hline
\end{tabular}

\section{Appendix 2}

\section{Nonsense Medications}

"good”, “ahn”, “one”, “yes”, “nore”, “jetson”, “exelium”, “hgygu”, "borg”, "medizel”, "gius”, "metrolmsop”, "metrokoloious", "gtreth", "as", "tyroid”, "trats", "unknown”, "dol”, “idk”, "unsure”, "capsules”, "oxy”, "fevers", "sustatin"

\section{Nonspecific Medications}

"birth control", "after sun lotion", "callous liquid", "muscle relax", "bandage”, "multi-vitamin", "multivitamins", "oneaday", "ear drops", "vitamins", "Flintstone vitamins"

\section{Storage Not Specified on Package Label/Lexicomp}

Hydrangea root, Therapain, Arnicare 